\title{
APPLAYING TRANSITION ACTION DETAIL STRATEGY ON WRITTEN TEXT OF EFL YOUNG LEARNERS
}

\author{
${ }^{1}$ Yeasy Agustina Sari $\&{ }^{2}$ Suhono \\ ${ }^{1}$ Institut Agama Islam Negeri Metro \\ ${ }^{2}$ Institut Agama Islam Ma'arif NU Metro Lampung \\ 1YYeasy120708@gmail.com \& ²suhono120708@gmail.com
}

\begin{abstract}
Abstrack
Mastering English, as foreign language need a lot of time since it is a continuing process. English foreign language of young learners, however, can't be mastered by memorizing. The young learners should have strategy, which can be used as the direction of the classroom activites to help the students enhancing of language skill, specially in writting. There were the problem to be solved in this study, namely the students have difficult to construct the written text. The strategies which were used in the learning process were boring. Hence, the researcher tried to solve students' difficulty in written text through Transition Action Detail Strategy. This study focused on two variables. The independent variable was Transition Action Detail Strategy, meanwhile dependent variable was written text. The researcher used true experimental design which consist of control group and experimental group. The subject of this research was students of young learner at the eight grade of English Course at Payakumbuh.

The result revealed that Transition Action Detail Strategy was a good strategy that can influence the students' written text. By using df.70, the writer not found it in the table. Because 70 was higher than 60 and smaller than 120. Then, the results from interpolation by using $d f .70$, it could be known that the critical value of $t_{\text {-table }}$ for the $5 \%$ level was 1.990 , the critical value of $t_{\text {-table }}$ for the 1\% level was 2.638. From these all the data analysis, it can be seen that $t_{\text {-observed }}$ (4.763) was higher than $t_{\text {-table }}(5 \%=1.990,1 \%$ $=2.638)$. The data confirm that $t_{\text {-observed }}$ is higher than $t_{\text {-table, }}$ therefore it can be inferred that Ha is accepted and Ho is rejected. It means that there is significant influence of applying Transition Action Detail Strategy on Wwritten Text of Young learners.
\end{abstract}


Key words: Transition Action Detail Strategy, Young Learners, English Foreign Language, English Course.

\section{Abstrak}

Menguasai bahasa Inggris, sebagai bahasa asing membutuhkan banyak waktu karena ini adalah proses yang berkelanjutan. Bahasa asing bahasa Inggris untuk pelajar muda, bagaimanapun, tidak dapat dikuasai dengan menghafal. Peserta didik muda harus memiliki strategi, yang dapat digunakan sebagai arah kegiatan kelas untuk membantu siswa meningkatkan kemampuan bahasa, khususnya dalam penulisan. Ada masalah yang harus dipecahkan dalam penelitian ini, yaitu siswa sulit menyusun teks tertulis. Strategi yang digunakan dalam proses pembelajaran itu membosankan. Oleh karena itu, peneliti mencoba memecahkan kesulitan menulis teks melalui Strategi Detail Aksi Transisi. Penelitian ini difokuskan pada dua variabel. Variabel independennya adalah Transition Action Detail Strategy, sedangkan variabel dependennya adalah teks tertulis. Peneliti menggunakan rancangan eksperimen yang benar yang terdiri dari kelompok kontrol dan kelompok eksperimen. Subjek penelitian ini adalah siswa pelajar muda kelas VIII di Payakumbuh. Hasilnya menunjukkan bahwa Transition Action Detail Strategy merupakan strategi yang baik yang dapat mempengaruhi teks tertulis siswa. Dengan menggunakan df.70, penulis tidak menemukannya di tabel. Karena 70 lebih tinggi dari 60 dan lebih kecil dari 120. Kemudian, hasil dari interpolasi dengan menggunakan df.70, dapat diketahui bahwa nilai kritis t-tabel untuk tingkat 5\% adalah 1.990, nilai kritis t-tabel Untuk level 1\% adalah 2.638. Dari semua analisis data tersebut, dapat dilihat bahwa t-observasi (4.763) lebih tinggi dari t tabel $(5 \%=1.990$, $1 \%=2.638$ ). Data mengkonfirmasi bahwa t-observasi lebih tinggi dari t tabel, oleh karena itu dapat disimpulkan bahwa Ha diterima dan Ho ditolak. Artinya ada pengaruh yang signifikan dari penerapan Strategi Detail Transisi tentang Teks Wajar Siswa Muda. 
Kata kunci: Transisi Action Detail Strategy, Young Learners, Bahasa Inggris Asing, Kursus Bahasa Inggris.

\section{INTRODUCTION}

Language is a means of communication among individuals. It is a signaling system which is operated with symbolic vocal sound and which is used by a group of people for to get the purpose of communication. It is a special characteristic of human or it can also be regarded as one of human criteria, because only human beings speak a language. The English language is one of the international languages that are widely used in the world. English has been used by many people from different countries.

English in Indonesia is the first foreign language. So, mastering English as a foreign language is not as simple as learning English as a national language. The teachers and the students must understand the strategy that will be used in English teaching and learning process. Then, it must suitable in teaching and learning process. Because, learning English with suitable strategy can aids the students to understand English material well. Afterward, the students should have four language skills such as: listening, speaking, reading and writing. One of the objectives of teaching English of young learner is the students have a good in writing to support the language skills which are being learned.

Writing is one of an important aspect in language learning. Writing involves transferring a message from our thoughts using language in the written from. By writing, the students can share information and ideas in the written form. They can express all of their ideas and thoughts, to provide information for the reader to 
persuade the reader to do something. To write well, the people must have good writing capabilities too. In teaching writing, there are kinds of texts; one of them is about narrative text. Narrative text describes an event, feeling or experience in story form or in the order the details of the event happened

In writing narrative there is a posibility that the student doesn't know how to express their idea to tell something. To motivate them, the teacher should find out some strategy that can attract the students' interest. Strategy is a plan to reach the goal through the learning process. This activity can be done by the teachers or the students in teaching and learning process. In teaching learning process, strategy is very urgent to decide all plans in learning process. Strategy can help the teacher in explaining or teaching the material in order to their students easier to understand what we learn in learning process. One of suitable strategy is Transition Action Detail Strategy. This strategy can be used to enhance the students in written text because it helped them what to write through Transition Action Detail Strategy. Applying Transition Action Detail Strategy can motivate and improve the students in learning process of narrative text. Then, they have the steps and the way about what they wrote.

The pre-survey was done on January, $12^{\text {th }} 2015$. They are 36 students at the eighth class of students' English Course at Payakumbu. The data of the pre-survey result can be seen the highest score is 70 that consist of 8 students. The lowest score is 55 that consist of 8 students and the average score is 61 of the total students. Based on the pre-survey result. the writer found that the students were difficulties to construc narrative text, the 
students have difficulties to express their idea into narrative text, the students lack vocabularies and the strategies which are used in the learning process are boring. From the problems above, the writer conducted the research Applying Transition Action Detail Strategy on Written Text of Young Learners

\section{THEORETICAL REVIEW}

\section{The Notion of Transition Action Detail Strategy}

Strategy, which help the students in achievement of certain knowladge and skill on certain language aspect, .is one of teaching agenda that indicates the direction of the classroom activities. It is a plan to operate or to manage an event of the system to reach the goals.In learning English it can be used to simplify learning English process since as a guidence and as a hint in teaching learning process for the teacher, while for the students it can be used to simlpyfy in learning process. Transition Action Detail Strategy is one of strategy in teaching writing process. It can be divided into three definition, namely transition, action and detail. Bellow the definition of Transition Action Detail Strategy:

a) Transition

Tarigan claim that transtion is chain-link as a connector among paragraph. It has the function as a connector nearby two idea paragraph. ${ }^{1}$ It means that as a support paragraph in order to the paragraph can provide coherence each other. Furthermore, Joy M. Reid poin outtransition like a connector in sentence and different

${ }^{1}$ Djago Tarigan, Menulis Paragraph dan Pegembangannya. Angkasa Bandung. Bandung, 1981, p.15 
grammatical uses. ${ }^{2}$ Peha supporting this idea that"transition is short pharse like "Then" or "After a while" or "in the beginning" that help to introduce each new action in these sequence. You don't' have to have a transition for each action. But, transition can help your writing flow more smoothly from section to section. ${ }^{3}$ As a result, it can be inferred that transition as a signal relationship among the sentences of the paragraph and has the function as support coherence among the sentence and leads the sentence which will be discussed. So, the transition in the sentences is connecting a topic to one another topic on the paragraph.

b) Action

Action has further suggestedthat is actual events (the thing that happened) listed in the order in which they occurred. ${ }^{4}$ So, in this scene the writter need the event to describe the action in order to know what going on. In conclusion action isthe process event which is doing by the people based on their sequence of events to getthe purpose. This is the character's people do and says that happens to them.

c) Detail

It is additional information about each action. For each action, your audience will probably have two or three important questions you need to answer. These answers are

\footnotetext{
${ }^{2}$ Joy M. Reid, The Process of Composition, op. cit., p.70

${ }^{3}$ Steve Peha, The Writing Teacher's Strategy Guide, Teaching That Making Sense New York, 2003, p. 38

${ }^{4}$ Steve Peha,loc.cit.
} 
your details. ${ }^{5}$ In conclusion, detail is the way to support information an action in one paragraph or more in other to be completed. Detail is extremely important part of writing. Because without details it's hard for a reader to know exactly what a writer is trying to say. It means that this Transition Action Detail Strategy can be used for the students to write narrative text by concerning the three basic structures such as transition, action, detail. Furthermore, through this strategy can engage students' imagination or experience to make easier to write narrative text. From the explanation about the definition of each word Transition Action Detail Strategy above, these statements can be explained the theory of Transition Action Detail Strategy as follows:

Furthermore the scholars Peha and Margot suggested that every story really just a collection of scene. So writing a story, whether it's something from your imagination or something from your life, is really about writing scene. As reders move from scene to scene, they really on basic story elements to make sure they don't lose their way." "It means that the scene or event is really needed to make writing a story. Because through our imagination or experience makes easier to find our idea. Peha \&Margot gives the statment about Transition Action Details Strategy. They stated that the "Transition Action Detail Strategyis

\footnotetext{
${ }^{5}$ Steve Peha,loc.cit.

${ }^{6}$ Steve Peha\& Margot Carmichael Laster, Be a Better Writer.Your
}

Guide To The Writing Life!.Teaching That Making Sense, Inc, New York, 2006, p. 57 
great for telling stories, talking about historical events, summarizing and many other sequential writing tasks." It also perfect tool for this. Draw a 3 column chart with six or seven rows one a piece of paper. It is very useful. Opportunities to describe a sequence of events in narrative fiction and non-fiction writing. ${ }^{8}$ Based on the statement above Transition Action Detail Strategy is a great way strategy that can help the students to estimates a scene in written form thier fiction or non-fiction eventthrough the sequence of events. It focus on important details about the writing their event or activity. Through this strategy, the students can express their ideas in written form.

\section{The Process of Transition Action Detail Strategy}

To make easier write a narrative text by applying Transition Action Details Strategy, there are processes that help the students to begin their write. It is pick a scene from our story that we would like to start writing. Here under the steps of Transition Action Details Strategy; the first, you must make 3 columns in your paper consist of transition, action, detail. Put the thing that happened in the first Action column. Action is the actual events (the things that happened) listed in the order in which they occurred." ${ }^{9}$ On the action column you can describe your action. It describes what it is happening. A sentence or two about the main action is all you really need. If this story is about you, describe what you are doing. Then, if the story about folklore, legend, etc, you will take from

\footnotetext{
${ }^{7}$ Steve Peha \&Margot Carmichael Laster, loc.cit.

${ }^{8}$ Steve Peha, loc.cit.

${ }^{9}$ Steve Peha \&Margot Carmichael Laster, op.cit., p.62
} 
your experience what you have known. So the people will know what's going on.

When you finish the action column, add the couple of details for each action. In this steep, detail is "additional information about each action." ${ }^{\text {I0 }}$ It has the function to develop the sentence for each action. In order the paragraph completed. On detail column, try to put two or three really good details for each action.

Finally, come up with simple phrase in the Transition column that introduces each action. Many transitions can go at the beginning, middle, or at the end of the sentence. ${ }^{11}$ It's mean that to make coherence among the sentences, we can use the words or phrases as a connector in the beginning, middle or the end of sentence in order to there are connection from the action that comes before. But, we may leave a few transitions on the first column. Because, not every action needs to be introduce with the transition.

Based on the quotation above, it can be inferred that the process of Transition Action Detail Strategy is starting form Action (Describing action or event). Furthermore, additional information about each action and the last come up with transition that introducing the action. After that make a sentence from the 3 column and the last each sentence can be included into a narrative paragraph. You must make 3 columns in your paper assignment. Afterward, write each 3 columns consist of Transition, Action, and Detail.

\footnotetext{
${ }^{10} \mathrm{Ibid}$, p. 62

${ }^{11}$ Chintya A. broadman\&JiaFydenberg, Writing to Communicate, Pearson Longman, America, 2008, p.58
} 
The three columns of Transition Action Detail Strategy are very essential to make easier write a narrative text. Because, we can express our idea in written form through these columns regularly and effectively. When filling out the Transition Action Detail, starting in the first action's column, fill in the first box with the first thing that happens. When you finish write in the first action's column, add an information couple of details base on each action. Audience will probably have two or three important questions you need to answer. These answers are your detail. In this way, you can probably talk to your classamtes or friends about your details. Then, put the transition as introduce the action and as connector to the next sentence. Afterward, come up again with simple phrases in the transition columns that introduce the action.

Table 1

The Example of Transition Action Detail Strategy

\begin{tabular}{|c|c|c|}
\hline $\begin{array}{c}\text { TRANSITION } \\
\text { (Introduce the action) }\end{array}$ & \begin{tabular}{l}
\multicolumn{2}{c}{ ACTION } \\
(Describe what \\
happen)
\end{tabular} & $\begin{array}{l}\text { DETAIL } \\
\text { (Answer audience } \\
\text { question) }\end{array}$ \\
\hline One day & $\begin{array}{l}\text { A huge snake got in } \\
\text { my aunt's living } \\
\text { room }\end{array}$ & $\begin{array}{l}\text { She was very } \\
\text { frightened } \\
\text { But she tired to } \\
\text { manage herself to } \\
\text { be quiet }\end{array}$ \\
\hline Unfortunately & She failed to do it & $\begin{array}{l}\text { she screamed put } \\
\text { very loudly and } \\
\text { then called some } \\
\text { neighbors for some } \\
\text { help }\end{array}$ \\
\hline After that & She ran out & $\begin{array}{l}\text { and in to try to } \\
\text { chase the snake out } \\
\text { of the room }\end{array}$ \\
\hline
\end{tabular}




\begin{tabular}{|c|c|c|}
\hline & & $\begin{array}{l}\text { but she failed to do } \\
\text { so }\end{array}$ \\
\hline & $\begin{array}{l}\text { Some neighbor } \\
\text { using salt to chase it } \\
\text { away }\end{array}$ & $\begin{array}{l}\text { She went to kitchen } \\
\text { to get a cup of salt }\end{array}$ \\
\hline & $\begin{array}{l}\text { Using her mind } \\
\text { hand she spread the } \\
\text { salt over the snake }\end{array}$ & $\begin{array}{l}\text { The floor of the } \\
\text { living room }\end{array}$ \\
\hline Not long after that & $\begin{array}{l}\text { The snake slowly } \\
\text { began to move its } \\
\text { body and through } \\
\text { the opened the door }\end{array}$ & $\begin{array}{l}\text { It began to leave the } \\
\text { room }\end{array}$ \\
\hline & $\begin{array}{l}\text { My aunt was so } \\
\text { relieved }\end{array}$ & $\begin{array}{l}\text { To see the snake } \\
\text { leaving room } \\
\text { without making any } \\
\text { harm to anybody }\end{array}$ \\
\hline
\end{tabular}

After making 3 columns and fill up each 3 columns, the students have more than enough material to write a complete scene or story. Now, they can move or copy into a complete narrative story in the narrative text.

One day, a huge snake got in my aunt's living room. She was very frightened, but she tried to manage herself to be quiet. Unfortunately, she failed to do it, she screamed out very loudly and then callled some neighbors for some help. After that, she ran out and in to try to chase the snake out of theroom, but she failed to do so. Some neighbors suggested using salt to chase it away. She way went to the kitchen to get a cup of salt. Using her righ hand, she spread the salt over the snake and the floor of the living room. Not long after that, the snake slowly began to move its body and through the opened door, it began to leave the room. My aunt was so relieved to see the snake leaving the room without making any harm to anybody.

The students can write easier narrative text through the Transition Action Details Strategy. It means to solve a terribly 
troubling problem for the students. The students give themselves a chance to focus on the students' topic and can make their writing richer and more detail. In this strategy can be founded specific ideas and also about the topic of the sentence in a paragraph. So that, the students can expresses an ideas through this strategy to be a good narrative text

To develop the students' narrative text writing ability, here are the tips by applying Transition Action Details Strategy:

Testing out your sequencing. The thing I like best about this strategy is that it lets me test out my story little by little so I can make sure it's right. I start by filling in the first and last "Action" boxes. This way I know for sure how I want my story to start and end. Then I fill in the boxes in the middle. Finally, I read it over from top to bottom to make sure that things are in the right order and that I haven't left anything out. At this point, it's easy to make a change if I have to switch something around, add in something new, or take something out. Once the "Action" column is good, I feel confident that the rest of the story will work out well, too.

Filling in the details. This is just like filling in the details of an Idea-Details chart. You use the same approach, too. Look at your "Action" and then think about the questions your audience would ask you about it. Or, if you like, share your writing with the class or with a partner and see what questions people ask you. The difference between the "Details" column in this strategy and the "Details" column in Idea-Details is that you don't need as many details for things to work out. Try to come up with two to four really good details for each action. That will usually be plenty.

Don't worry about the transitions. If you can't think of any transitions, or if you feel you don't need them, leave those boxes blank. First of all, not every action needs to be introduced with a transition. Second, when you start to 
draft, you'll probably put some transitions in naturally without thinking about it. ${ }^{12}$

\section{RESEARCH METHOD}

The researcher used true experimental design which consists of control group pre - test post - test design. Since it was a true experimental research which applying pre - test, post - test control group design the writer administered pre - test and post test to both experimental and control group. The sample of the research was Students' English course at Payakumbuh in the eighth calss VIII3 which consists of 36 students and the eighth class VIII4 which consist of 36 students. The eighth class VIII3 as the control class and the eighth class VIII4 as the experimental class.

\section{FINDING AND DISCUSSION}

\section{a. The result students pre test}

The Purpose of giving pre-test in this research is to know the students' writing skill before treatment. The result of pre-test experimental class, the average score from 36 students was 60.27 . The students who got the score lower than 70 was twenty eight students, the students who got the score 70 was six students and the students who got the score more than 70 was two students. So that, the students have not reached minimum standard (KKM). It can be concluded that the result of the students' narrative text in pre-test was poor. Based on the table above, the writer measured the class interval that is 4.54. After knowing the class interval, the data put on the table of frequency distribution as follows:

\footnotetext{
${ }^{12}$ Steve Peha, op.cit., p. 46
} 
Table 2

\begin{tabular}{|c|c|c|}
\hline Class Interval & Frequency & Percentage \% \\
\hline $45-48$ & 3 & 8.3 \\
$49-52$ & 2 & 5.6 \\
$53-56$ & 5 & 13.9 \\
$57-60$ & 12 & 33.3 \\
$61-64$ & 2 & 5.6 \\
$65-68$ & 4 & 11.1 \\
$69-72$ & 8 & 22.2 \\
\hline Total & 36 & $100 \%$ \\
\hline
\end{tabular}

Based on the table of frequency distribution above, it can be inferred that 28 students got score lower than 70 . It means that 77.8 $\%$ the students has not reached minimum standard (KKM). The average score of pre-test was 60.27 . It shows that the result of the students' writen text was poor. It was one reason why the researcher used the Transition Action Detail Strategy. The researcher has done pre-test to the control class too. Based on the result of pre-test control class, the average score from 36 students was 61.69. The students who got the score lower than 70 was twenty six students, the students who got the score 70 was eight students and the students who got the score more than 70 was two students. So that, the students have not reached minimum standard (KKM). It can be concluded that the result of the students' written text in pre-test was poor. Based on the table above, the class interval was 4.83 or 5 . After knowing the class interval, the data was put on the table of frequency distribution as follows:

Table 4

\begin{tabular}{|c|c|c|}
\hline Class Interval & Frequency & Percentage $\%$ \\
\hline $46-50$ & 2 & 5.6 \\
$51-55$ & 7 & 19.4 \\
$56-60$ & 11 & 30.5 \\
$61-65$ & 6 & 16.7 \\
$66-70$ & 8 & 22.2 \\
\hline
\end{tabular}


15

E-ISSN 2548-7892. P-ISSN 2548-7892. Vol. 2. No.1, Juni 2017, pp.1-24

\begin{tabular}{|c|c|c|}
\hline $71-75$ & 2 & 5.6 \\
\hline Total & 36 & 100 \\
\hline
\end{tabular}

Based on the table of frequency distribution above, it can be inferred that 26 students got score lower than 70 . It means that $72.2 \%$ students have not reached minimum standard (KKM). The average score of pretest was 61.69. It shows that the result of the students' written text in pre-test was low.

\section{b. The Result of the Students' Post-test}

After the writer gave the material about the narrative text, the pretest instrument was different from the post-test instrument, but has the same type and difficulty level. The post-test was carried out in order to know the students' ability after the treatments. Based on the result of post-test experimental class, the average score from 36 students was 71.83. The students who got the score more than 70 was nineteen students, the students who got the score 70 was seven students and the students who got the score lower than 70 was ten students. So that, the students have reached minimum standard (KKM). It can be concluded that they success in teaching and learning process in the class. Based on the table above, the class interval was 4.83 or 5 . After knowing the class interval, the data was put on the table of frequency distribution as follows:

Table 6

\begin{tabular}{|c|c|c|}
\hline Class Interval & Frequency & Percentage $\%$ \\
\hline $54-58$ & 5 & 13.9 \\
$59-63$ & - & - \\
$64-68$ & 5 & 13.9 \\
$69-73$ & 8 & 22.2 \\
$74-78$ & 11 & 30.6 \\
$79-83$ & 7 & 19.4 \\
\hline
\end{tabular}




\begin{tabular}{|c|c|c|}
\hline Total & 36 & 100 \\
\hline
\end{tabular}

Table 11 shows that the result of post-test can fulfill minimum standard (KKM) where $72.3 \%$ (26 students) got score more than 70 . The average score of post-test was 71.83 . It shows that they are successful in teaching and learning process in the class. The writer also conducted post-test for the control class.

Based on the result of post-test control class, the average score from 36 students was 65.66. The students who got the score more than 70 was six students, the students who got the score 70 was four students and the students who got the score lower than 70 was twenty six students. So that, the students have not reached minimum standard (KKM). It can be concluded that the result of the students' text in pre-test was low. Based on the table above, the class interval was 5.83 or 6 . After knowing the class interval, the data was put on the table of frequency distribution as follows:

Table 8

The Frequency Distribution of the Students' Score in Post-test (Control Class)

\begin{tabular}{|c|c|c|}
\hline Class Interval & Frequency & Percentage $\%$ \\
\hline $45-50$ & 1 & 2.8 \\
$51-56$ & 1 & 2.8 \\
$57-62$ & 10 & 27.8 \\
$63-68$ & 14 & 38.9 \\
$69-74$ & 4 & 11.1 \\
$75-80$ & 6 & 16.6 \\
\hline Total & 36 & 100 \\
\hline
\end{tabular}

From the table frequency above, it can be seen that there were 26 students $72.3 \%$ who get score less than 70 as the minimum standard (KKM) and 10 students $(27.7 \%)$ get score more than 70 . 
Iqra’ (Jurnal Kajian Ilmu Pendidikan)

17

E-ISSN 2548-7892. P-ISSN 2548-7892. Vol. 2. No.1, Juni 2017, pp.1-24

it can be said that the results in experimental class are better than these of control class.

\section{c. Hypothesis Testing}

After giving test, the writer analyzed the data by using t-test in order to prove whether there is any influence between experimental classes which applying Transition Action Detail Strategy in written text and control class didn't applying Transition Action Detail Strategy Students' English course at Payakumbuh.

a. Preparing the table in order to proved whether there is any difference between the experimental class and the control class at the Eighth grade of english course payakumbuh.

Table 9

\begin{tabular}{|c|c|c|c|c|c|c|c|}
\hline \multicolumn{4}{|c|}{ Experimental Class } & \multicolumn{5}{c|}{ Control Class } \\
\hline $\begin{array}{c}\text { Subjec } \\
\text { t }\end{array}$ & $\begin{array}{c}\text { Pretest } \\
(\mathbf{X 1 )}\end{array}$ & $\begin{array}{c}\text { Posttest } \\
\text { (X2) }\end{array}$ & $\begin{array}{c}\text { Gain } \\
(\mathbf{X})\end{array}$ & $\begin{array}{c}\text { Subjec } \\
\text { t }\end{array}$ & $\begin{array}{c}\text { Pretest } \\
(\text { Y1) }\end{array}$ & $\begin{array}{c}\text { Posttest } \\
(\text { Y2) }\end{array}$ & $\begin{array}{c}\text { Gain } \\
(\mathbf{Y})\end{array}$ \\
\hline $\mathrm{At}$ & 60 & 75 & 15 & $\mathrm{Ar}$ & 60 & 68 & 8 \\
\hline $\mathrm{Ap}$ & 55 & 60 & 5 & $\mathrm{Am}$ & 54 & 60 & 6 \\
\hline $\mathrm{As}$ & 60 & 74 & 14 & $\mathrm{Aw}$ & 55 & 58 & 3 \\
\hline $\mathrm{Ag}$ & 55 & 70 & 15 & $\mathrm{Ap}$ & 70 & 65 & -5 \\
\hline $\mathrm{Ab}$ & 58 & 54 & -4 & $\mathrm{Ah}$ & 75 & 80 & 5 \\
\hline $\mathrm{Au}$ & 50 & 65 & 15 & $\mathrm{Ai}$ & 70 & 68 & -2 \\
\hline $\mathrm{Bd}$ & 70 & 78 & 8 & $\mathrm{Ba}$ & 56 & 60 & 4 \\
\hline $\mathrm{Bk}$ & 72 & 68 & -4 & $\mathrm{Bg}$ & 54 & 55 & 1 \\
\hline $\mathrm{Dr}$ & 65 & 65 & - & $\mathrm{Bs}$ & 46 & 45 & -1 \\
\hline $\mathrm{Di}$ & 60 & 78 & 18 & $\mathrm{Bm}$ & 65 & 60 & -5 \\
\hline $\mathrm{Dy}$ & 50 & 62 & 12 & $\mathrm{Bp}$ & 58 & 65 & 7 \\
\hline $\mathrm{Dp}$ & 45 & 70 & 25 & $\mathrm{Bd}$ & 60 & 68 & 8 \\
\hline $\mathrm{Da}$ & 58 & 70 & 12 & $\mathrm{Bh}$ & 60 & 65 & 5 \\
\hline $\mathrm{Dr}$ & 65 & 80 & 15 & $\mathrm{Co}$ & 70 & 70 & - \\
\hline $\mathrm{De}$ & 70 & 70 & - & $\mathrm{Cs}$ & 60 & 75 & 15 \\
\hline
\end{tabular}




\begin{tabular}{|c|c|c|c|c|c|c|c|}
\hline Ff & 60 & 80 & 20 & $\mathrm{Cv}$ & 54 & 60 & 6 \\
\hline $\mathrm{Iw}$ & 58 & 80 & 22 & $\mathrm{Ev}$ & 52 & 65 & 13 \\
\hline $\mathrm{Jp}$ & 48 & 70 & 22 & $\mathrm{Fa}$ & 58 & 58 & - \\
\hline $\mathrm{Ka}$ & 55 & 83 & 28 & $\mathrm{Fh}$ & 70 & 60 & -10 \\
\hline $\mathrm{MK}$ & 72 & 80 & 8 & $\mathrm{Fa}$ & 60 & 64 & 4 \\
\hline $\mathrm{Mh}$ & 65 & 75 & 10 & $\mathrm{Kr}$ & 60 & 70 & 10 \\
\hline $\mathrm{Mr}$ & 70 & 70 & - & $\mathrm{Mf}$ & 60 & 75 & 15 \\
\hline $\mathrm{Mw}$ & 58 & 72 & 14 & $\mathrm{Mk}$ & 64 & 65 & 1 \\
\hline $\mathrm{Na}$ & 60 & 65 & 5 & $\mathrm{Mc}$ & 65 & 65 & - \\
\hline $\mathrm{Nf}$ & 65 & 55 & -10 & $\mathrm{Mw}$ & 55 & 60 & 5 \\
\hline $\mathrm{Ob}$ & 64 & 65 & 1 & $\mathrm{Mm}$ & 70 & 80 & 10 \\
\hline $\mathrm{Pa}$ & 60 & 70 & 20 & $\mathrm{Mv}$ & 70 & 80 & 10 \\
\hline $\mathrm{Ps}$ & 55 & 80 & 25 & $\mathrm{Ns}$ & 50 & 65 & 15 \\
\hline $\mathrm{Rf}$ & 45 & 58 & 13 & $\mathrm{Nr}$ & 65 & 65 & - \\
\hline $\mathrm{Rw}$ & 58 & 75 & 17 & $\mathrm{Pi}$ & 72 & 80 & 8 \\
\hline $\mathrm{Rr}$ & 70 & 78 & 8 & $\mathrm{Ra}$ & 70 & 70 & - \\
\hline $\mathrm{Wp}$ & 70 & 83 & 13 & $\mathrm{Rw}$ & 70 & 65 & -5 \\
\hline $\mathrm{Wc}$ & 58 & 75 & 17 & $\mathrm{Ra}$ & 55 & 60 & 5 \\
\hline $\mathrm{Yd}$ & 70 & 78 & 8 & $\mathrm{Rc}$ & 58 & 60 & 2 \\
\hline $\mathrm{Ym}$ & 54 & 75 & 21 & $\mathrm{Tm}$ & 65 & 65 & - \\
\hline $\mathrm{Za}$ & 62 & 80 & 18 & $\mathrm{Wp}$ & 65 & 70 & 5 \\
\hline$\left(\sum \mathrm{X}\right)$ & 2170 & 2586 & 426 & $\left(\sum \mathrm{Y}\right)$ & 2221 & 2364 & 143 \\
\hline$(\bar{x})$ & 60.27 & 71.83 & & $(\bar{y})$ & 61.69 & 65.66 & \\
\hline
\end{tabular}

The Authentic Table of the Differencess Between Experimental Class and Control Class of Students' English course at Payakumbuh

1. Putting data above into the formula of $t$-test in order to get $t$. observed

$$
\begin{array}{rlrl}
M_{X} & =\frac{426}{36} & M_{y} & =\frac{143}{36} \\
= & =11.83 & 3.97 & \\
\sum_{X^{2}} & =\sum_{X^{2}}-\frac{\left(\sum X\right)^{2}}{N} & \sum_{y^{2}} & =\sum_{y^{2}}-\frac{\left(\sum Y\right)^{2}}{N} \\
& =7662-\frac{(426)^{2}}{36} & & 1449-\frac{(143)^{2}}{36} \\
& =7662-5041 & & =1449-568.02 \\
& =2621 & & =880.98
\end{array}
$$


as follow :

Therefore the writer counted by using the formula of t-test

$$
\begin{aligned}
& t=\frac{M_{X}-M_{Y}}{\sqrt{\left(\frac{\sum X^{2}+\sum Y^{2}}{N_{X}+N_{Y} 2}\right)\left(\frac{1}{N_{X}}+\frac{1}{N_{Y}}\right)}} \\
& t=\frac{11.83-3.97}{\sqrt{\left(\frac{2621+880.98}{36+36-2}\right)\left(\frac{1}{36}+\frac{1}{36}\right)}} \\
& t=\frac{7.86}{\sqrt{\left(\frac{3.501 .98}{70}\right) x 0.055}} \\
& t=\frac{7.86}{\sqrt{50.028 x 0.055}} \\
& t=\frac{7.86}{\sqrt{2.75}} \\
& t=\frac{7.86}{1.65} \\
& t=4.763
\end{aligned}
$$

\section{d. Interpretation}

Last but not list, after applying the treatment the writer found tobserved was 4.763 Whereas, the determined of hypothesis testing is, if the tobserved higher than ttable, Ha is accepted and Ho is rejected and on the other way $t_{\text {-observedsmaller thant-table }}$

1. Interpretation of tobserved

After $\mathrm{Ha}$ and Ho above were formulated, the writer consulted $t_{\text {-observed }}$ to $t_{\text {-table, }}$, as follows:

1). If is $t_{\text {-observedhigher than }} t_{\text {-table, }}$, Alternative Hypothesis (Ha) is accepted and Null Hypothesis (Ho) is rejected. 


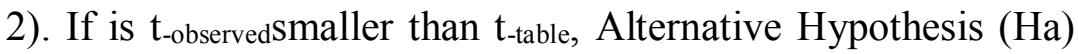
is rejected and Null Hypothesis (Ho) is accepted.

The critical value $t_{-o b s e r v e d}$ as 4.763 , the researcher interpret it based on the quotation above. It can be known that there was significant influence of applying Transition Action Detail Strategy toward the students' narrative text at Payakumbuh.

2. Statistical Significance

To know the critical value of t-test (t-observed), the writer firstly counted degree of freedom (df). The formulation of $\mathrm{df}=$ $\mathrm{Nx}+\mathrm{Ny}-2$.

$$
\begin{aligned}
\mathrm{df} & =\mathrm{Nx}+\mathrm{Ny}-2 \\
& =36+36-2 \\
& =70
\end{aligned}
$$

After considering the t-test table by using df 70 , the researcher not found it in $\mathrm{t}_{\text {table. }}$. So it was done interpolation because 70 are higher than 60 and lower than 120 .

Table 10

Critical Value of $t_{\text {-table }}$

\begin{tabular}{|c|c|c|}
\hline Level & $\mathbf{5 \%}$ & $\mathbf{1 \%}$ \\
\hline df 60 & 2.000 & 2.660 \\
\hline df 120 & 1.980 & 2.617 \\
\hline
\end{tabular}

\begin{tabular}{|l|c|c|}
\hline Interpolation & $\mathbf{5 \%}$ & $\mathbf{1 \%}$ \\
\hline $\mathrm{df} 60+\mathrm{df}$ & $2.000+1.980 / 2$ & $2.660+$ \\
$120 / 2$ & & $2.617 / 2$ \\
\cline { 2 - 3 } & 1.990 & 2.638 \\
\hline
\end{tabular}


Iqra’ (Jurnal Kajian Ilmu Pendidikan)

21

E-ISSN 2548-7892. P-ISSN 2548-7892. Vol. 2. No.1, Juni 2017, pp.1-24

From all data analysis above, it can be known that:

$\mathrm{t}_{\text {-observed }}=4.763$

$\mathrm{t}_{\text {-table, }}=1.990(5 \%)$ and $2.638(1 \%)$

The data confirm that tobserved was higher than ttable. Therefore it can be inferred that Alternative Hypothesis (Ha) is accepted and Null Hypothesis (Ho) is rejected. It means that there was significant influence of applying Transition Action Detail Strategy toward the students' narrative text at English Course of Payakumbu. The Transition Action Detail Strategy could influence of the students' narrative text writing ability because this strategy helped the students to make correlated sentence among the paragraph and to identify the main idea through three steeps they are transition, action and detail. It means that in the first action column described what it was happening. When finished the action column, added the couple of details for each action. Because, it could develop the sentence for each action. Finally, come up with simple phrase in the Transition column that introduces each action. Many transitions can go at the beginning, middle, or at the end of the sentence. It's mean that to make coherence among the sentences, we can use the words or phrases as a connector in the beginning, middle or the end of sentence in order to there are connection from the action that comes before. But, we may leave a few transitions on the first column. Because, not every action needs to be introduce with the transition. So, after identified the result of the $t_{\text {-observed }}$ above, this strategy aid the students in narrative text with minimum of error. 


\section{CONCLUSSION}

Based on the data collected the writer concludes that the Transition Action Detail Strategy was a good strategy that can influence the students' narrative text at English course at payakumbu. By using df.70, the writer not found it in the table. Because 70 was higher than 60 and smaller than 120. Then, the results from interpolation by using df. 70 , it could be known that the critical value of $t_{\text {table }}$ for the $5 \%$ level was 1.990 , the critical value of $t_{\text {-table }}$ for the $1 \%$ level was 2.638 . From these all the data analysis, it can be seen that $t_{\text {-observed }}(4.763)$ was higher than $t_{\text {table }}$ $(5 \%=1.990,1 \%=2.638)$.

The data confirm that $\mathrm{t}_{\text {-observed }}$ is higher than $\mathrm{t}_{\text {-table, }}$, therefore it can be inferred that $\mathrm{Ha}$ is accepted and Ho is rejected. It means that there is significant influence of applying Transition Action Detail Strategy toward the students' narrative text at English Course of Payakumbu.

\section{REFERENCES}

As Hornby. (2010) Oxford Advanced Learner's Dictionary, Oxford University Press, New York.

R.R Jordan. (2003),Academic Writing Course, Longman, England, Siahaan, Sanggam. (2008). Issues in Linguistics, Yogyakarta: Graha Ilmu,. . The English Paragraph, Yogyakarta: Graha Ilmu.

Davies, Paul. (2002) Success in English Teaching, Oxford University Press, New York.

M. Reid, Joy. (1988) The Process of Composition, Prentice-hall, Inc, New Jersey. 
S. Kane, Thomas. (2000)Essential Guide to Writing. Barkley Books. New York.

Furaidah, et.al. (2007) Advanced Writing, Universitas Terbuka, Jakarta.

Djuharie Setiawan Oton. (2009) Essay Writing, CV.Yrama, Widya, Bandung.

Iskandar Wassid \& Sunendar, Dadang. (2008) Strategi Pembelajaran Bahasa, PT remaja Rosda Karya, Bandung.

Tarigan Djago. (1981) Menulis Paragraph dan Pengembangannya. Angkasa Bandung. Bandung.

Peha, Steve. (2003) The Writing Teacher's Strategy Guide, Teaching That Making Sense, Inc, New York.

Peha, Steve \& Laster, Carmichael, Margot. (2006) Be a Better Writer: Your Guide to The Writing Life!.Teaching That Making Sense, Inc, New York.

A. Chintya, broadman \& Fydenberg, Jia. (2008) Writing to Communicate,Pearson Longman, America.

Mc. Crimon. (1983) Writing With a Purpose, Houthon Miffin, New York.

Grace Eudia \& Sudarwati. (2007) Look a Head. Jakarta, Erlangga.

Kumarsingh, Yongesh. (2006) Fundamental of Research Methodology and Statistics, New Age International (P) Limited, New Delhi, 2006.

Arikunto, Suharsimi. Prosedur Penelitian Suatu Pendekatan Praktek, PT. Rineka Cipta, Jakarta, 2006.

Kusnadi, Edi, Metodologi Penelitian,Ramayana Pers \& STAIN Metro, Metro,2008.

Nurgiyantoro, Burhan. Penilaian dalam Pengajaran Bahasa dan Sastra, BPFE Yogyakarta, Yogyakarta, 2001.. 
